Oḷegs Barānovs, Jānis Salmiņš, Irina Skribāne

\title{
Attālinātā darba ietekme uz produktivitāti un strukturālajām izmaiṇām
}

\section{levads}

Attālinātais darbs ir būtiski pieaudzis Covid-19 pandēmijas laikā. Lai palēninātu vīrusa izplatîšanos un aizsargātu darbiniekus, daudzi uzṇēmumi ir pārgājuši uz attālinātu darbu.

Latvijā plašu pāreju uz attālināto darbu veicina labā līmenī esošā interneta infrastruktūra (tostarp e-paraksts/e-identifikācija), valsts pārvaldes pakalpojumu augstais digitalizācijas līmenis, kā arī spēja veikt inovācijas, piemēram, izstrādājot platformas Saeimas un Ministru kabineta attālinātam darbam. Tomēr joprojām pastāv vairāki izaicinājumi: digitālo rīku un prasmju nodrošināšanai darbiniekiem, drošu un kvalitatīvu valsts digitālo pakalpojumu tālākai paplašināšanai utt.

Ilgtermiṇā attālināta darba iespēju plašāka izmantošana var būtiski ietekmēt tautsaimniecības strukturālās transformācijas procesu atsevišķos tirgos, nozarēs un reǵionos. Tas var mazināt ekonomisko aktivitāšu negatīvo ietekmi uz vidi, vienlaikus radot arī negatīvus blakusefektus, piemēram, nevienlīdzības palielināšanas riskus.

Autori sniedz izvērtējumu par attālinātā darba attīstības tendencēm un produktivitāti veicinošiem un ierobežojošiem faktoriem attālinātā darba apstākḷıs. Problemātikas analīzei izmantoti publiski pieejami statistikas dati no Centrālās statistikas pārvaldes (CSP), Eiropas Savienības Statistikas biroja (Eurostat), Eiropas Komisijas (EK), Ekonomiskās sadarbības un attīstības organizācijas (ESAO) u. c., kā arī zinātniskie pētījumi un veiktie apsekojumi. 


\section{Attālinātā darba būtība un attīstības tendences}

Tāldarbs, virtuālais darbs, attālinātais darbs, darbs mājās - šie termini parasti tiek izmantoti kā sinonīmi, savstarpēji aizstājami un ar to pašu pamata definīciju: tie visi nosaka darbu, kas netiek veikts tradicionālā birojā. ${ }^{1}$ Tomēr starp darbu mājās un attālināto darbu ir būtiska atšķirība. Darbs mājās ir tikai îslaicīga situācija. Pat pirms koronavīrusa dažiem darbiniekiem tika dota iespēja mēnesī strādāt noteiktu dienu skaitu mājās.

Darba aizsardzības likumā norādīts, ka attālinātais darbs ir tāds darba izpildes veids, ka darbs, kuru nodarbinātais varētu veikt darba devēja uzṇēmuma ietvaros, pastāvīgi vai regulāri tiek veikts ārpus uzṇēmuma, tai skaitā darbs, ko veic, izmantojot informācijas un komunikācijas tehnoloǵijas. Par attālināto darbu šā likuma izpratnē netiek uzskatīts darbs, kas tā rakstura dēḷ ir saistìts ar regulāru pārvietošanos. Savukārt statistikā ar attālināto darbu saprot darba izpildes veidu, kad darbs, kuru nodarbinātais varētu veikt uzṇēmuma ietvaros, pastāvīgi vai regulāri tiek veikts ārpus darba devēja uzṇēmuma, izmantojot informācijas un komunikācijas tehnologijas. ${ }^{2}$

\section{Attālinātā darba tendences līdz Covid-19 pandēmijai}

2019. gadā ES dalībvalstīs vidēji 14,4\% no kopējā nodarbināto skaita pilnībā vai daḷēji (dažreiz) strādāja attālinātā darba režīmā. Attālināti strādājošo daļa kopējā nodarbināto skaitā laikposmā no 2010. līdz 2019. gadam vidēji ES pieauga gandrīz 1,3 reizes (1. attēls).

Lielākais attālināto darbu strādājošo īpatsvars ES dalībvalstīs 2019. gadā bija Zviedrijā - 37,2\% no visiem strādājošajiem, kas gandrīz 2,5 reizes pārsniedza ES vidējo līmeni. Salīdzinot ar ES vidējo rādītāju, Latvijā attālinātā darba iespēju izmantošana bija gandrīz 3 reizes zemākà līmenī.

Valstis būtiski atškīinās ne tikai pēc attālinātā darbā nodarbināto ìpatsvara kopèjā nodarbināto skaitā, bet arī pēc tā, vai attālinātā darba režìms tika lietots pilnībā un daḷēji. Pēdējās desmitgades laikā ES dal̦ēji attālinātā darba režīmā strādājošo īpatsvars laikposmā no 2010. līdz 2019. gadam ir pieaudzis no 6\% lìdz 9\%. Vienlaikus jāatzīmē, ka pastāvīgi jeb piln̄ibā attālināto darba veicēju daḷa kopējā nodarbināto skaitā ir gandrīz nemainīga, saglabājoties minētajā laika periodā vidēji 5\% līmenī.

Brie, W. R. (2020). What Is a Remote Job? FlexJobs, December 3. Pieejams: https://www.flexjobs.com/ blog/post/what-is-a-remote-job

2 CSP. (2020). Attālināti nodarbināto darbinieku skaits. Pieejams: https://www.csb.gov.lv/lv/statistika/ covid19/attalinati-nodarbinato-darbinieku-skaits 


\section{1. attēls. Attālinātā darbā nodarbinātie ES dalībvalstīs}

(\% no kopējā nodarbināto skaita vecumā no 15 līdz 64 gadiem)

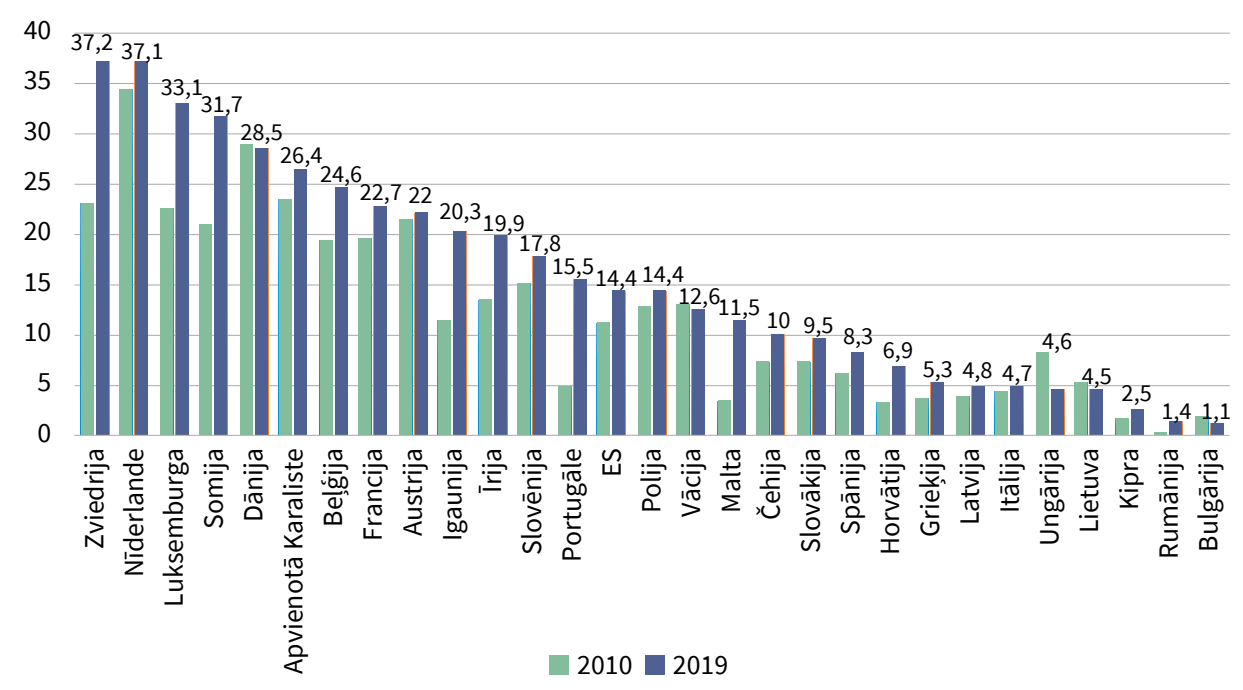

Avots: Eurostat.

Attālinātā darbā nodarbinātie Zviedrijā strādāja galvenokārt daḷēji attālinātā darba režīmā (31,3\%), kamēr pilnībā attālinātā darba režīmā 2019. gadā strādāja tikai 5,9\%. Lìderpozīcijās pēc pilnībā attālinātā darba režīmā 2019. gadā bija Nìderlande un Somija, kur šajā režīmā strādāja 14,1\% no kopējā nodarbināto skaita. Latvijā 2019. gadā pilnībā attālinātā darba režīmā strādāja 3\% no visiem nodarbinātajiem, dal̦ēji attālinātā darbā - 1,8\%.

Nozaru struktūras atšķirības ir viens no galvenajiem faktoriem, kas izskaidro attālinātā darba atšķirīgo izplatību ES valstīs. Zviedrijā, Luksemburgā, Somijā, Nīderlandē un Dānijā, kur nodarbināto daḷa augsto tehnoloǵiju un zinātnesietilpīgajās nozarēs kopējā nodarbināto skaitā ir lielāka, arī attālinātais darbs ir plašāk izplatīts. Attālināta darba režīma piemērošanu lielā mērā ietekmē ne tikai nozaru struktūra, bet arī biznesa pārvaldī̌sanas un darba organizēšanas modelis un kultūra. Salīdzinājumā ar vairākām ES dalībvalstīm ar līdzīgu zinātnesietilpīgajās nozarēs strādājošo daļu Latvija uzrāda zemāku attālināta darba strādājošo daḷu, kas varētu liecināt par esošā potenciāla nepilnīgu izmantošanu.

\section{Attālinātā darba tendences Covid-19 pandēmijas laikā}

Covid-19 pandēmijas izplatīšanos ierobežojošie pasākumi ir veicinājuši attālinātā darba režīma piemērošanas pieaugumu. Eurofound 2020. gada jūnijā un 
jūlijā veiktā e-aptauja ${ }^{3}$ rāda, ka vidēji ES 44,6\% aptaujāto darba n̦ēmēju pandēmijas laikā strādāja attālināti, kas būtiski pārsniedza ES vidējo tāldarbā strādājošo daļu 2019. gadā. Vislielākais darbinieku skaits, kas strādāja attālināti, bija Beḷgijā un Dānijā, attiecīgi $65,6 \%$ un $58,9 \%$ no aptaujāto skaita. Latvijā attālinātā darbā strādājošo daļa aptaujāto skaitā ir mazāka $(37,5 \%)$ nekā vidēji Eiropas Savienībā.

Saskaņā ar CSP datiem 2020. gada 2. ceturksnī attālināti strādājošie Latvijā veidoja gandrīz 20\% no nodarbināto kopskaita. Tomēr, uzlabojoties stāvoklim, viņu daḷa samazinājās, un gada 3. ceturksnī tikai 8,9\% darbinieku strādāja attālināti, 4. ceturksnī - 18\%. Ceturkšnu izteiktās svārstības liecina, ka cilvēki priekšroku dod darbam birojos un attālināta darba modelis ir nenoturīgs.

2020. gadā pandēmijas laikā darbu attālināti Latvijā veica $66 \%$ finanšu un apdrošināšanas darbību jomā strādājošo, 60\% informācijas un komunikācijas pakalpojumu darbinieku, gandrīz $28 \%$ valsts pārvaldes un aizsardzības, kā arī zinātnisko, administratīvo pakalpojumi un operāciju ar nekustamo īpašumu jomā strādājošie. Viszemākais (9,3\%) attālināti strādājošo darbinieku īpatsvars bija ražošanas sektorā.

\section{Attālinātā darba potenciāls - cik daudz darba var veikt attālināti}

Kopīgā Eiropas Komisijas un Eurofound 2020. gada pētijumā ${ }^{4}$ tika identificēts, ka ES ekonomikā 93\% finanšu pakalpojumu darbinieku var strādāt attālināti, kā arī 79\% informācijas un komunikāciju jomā un apmēram divas trešdal̦as darbinieku, kas nodarbojās ar nekustamo īpašumu, profesionālo, zinātnisko un tehnisko darbību, izglìtību un valsts pārvaldē. Pakalpojumu nozarēs ar zemāku tāldarba ipatsvaru ietilpst veselības aprūpe (30\%), mazumtirdzniecỉba (27\%) un izmitināšana un ēdināšana (16\%). Savukārt apstrādes rūpniecības un būvniecības nozarēs attālināta darba iespējas ir l̦oti ierobežotas - aptuveni 10-20\% no nozarē nodarbināto skaita.

Lìdzīgi secinājumi tika izdarīti arī Čikāgas Universitātes pētījumā. ${ }^{5}$ Tajā konstatēts, ka 63\% ASV darbavietu ir nepieciešama klātbūtne uz vietas un ka atlikušos $37 \%$ var veikt pilnībā attālināti. Starp profesijām ir lielas atškirīības. Vadītāji, pedagogi, informācijas un telekomunikāciju speciālisti, kā arī finanšu un tiesību jomā strādājošie lielākoties spēj strādāt attālināti. Turklāt ir vairākas

3 Working during COVID-19. Pieejams: https://www.eurofound.europa.eu/data/covid-19/workingteleworking

4 Sostero, M., Milasi, S., Hurley, J., Fernández-Macías, E., Bisello, M. (2020). Teleworkability and the COVID-19 crisis: a new digital divide?, Seville: European Commission, JRC121193. Pieejams: https:// ec.europa.eu/jrc/sites/jrcsh/files/jrc121193.pdf

Dingel, J. I., Neiman, B. (2020). How many jobs can be done at home? Chicago, IL: Becker Friedman Institute for Economics at the University of Chicago, April. Pieejams: https://bfi.uchicago.edu/wp-content/uploads/BFI_White-Paper_Dingel_Neiman_3.2020.pdf 


\section{2. attēls. Attālināta darba potenciāls un attālināti strādājošo daḷa 2020. gadā vidēji ceturksnī Covid-19 pandēmijas laikā Latvijā \\ (\% no nozarē strādājošo kopskaita, aprīlis-decembris)}

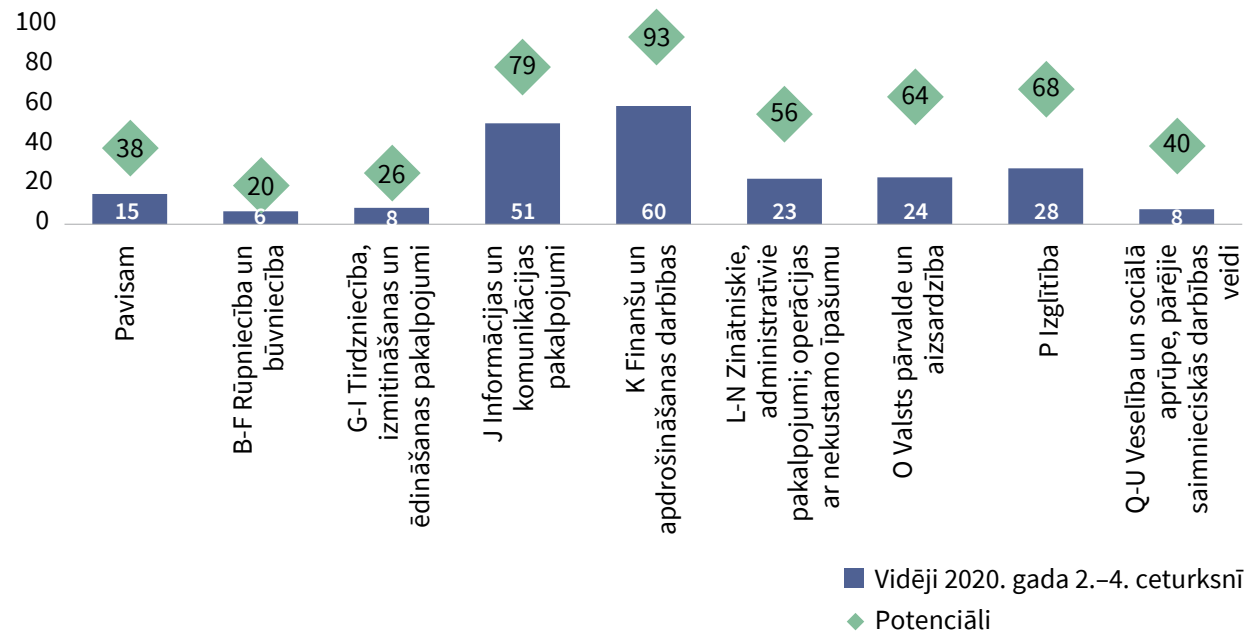

Avots: autoru aprēḳins.

profesijas, kurās attālināta darba iespējas ir ḷoti ierobežotas, piemēram, lauksaimniecībā, tirdzniecībā, būvniecībā. Kopumā tika secināts, ka attālināta darba iespējas ir lielākas tādās profesijās, kam nepieciešams augstāks izglīīibas līmenis.

Salīdzinot abu pētījumu rezultātus, jāsecina, ka attālināta darba potenciāla izvērtējums pa nozarēm ASV un ES kopumā ir līdzīgs. Atškirīibas novērtējumos var tikt skaidrotas ar nozaru struktūras dažādību abās ekonomikās, piemēram, ar nozares uzṇēmumu lieluma struktūru, nozarēs nodarbināto profesiju struktūru u. c.

Izmantojot kopīgajā Eiropas Komisijas un Eurofound 2020. gada pētījumā $\bar{a}^{6}$ aprēķinātos nozaru koeficientus par attālināta darba iespējām un CSP aptaujas rezultātus par attālināti strādājošajiem laika periodā no 2020. gada 2. līdz 4. ceturksnim, tika novērtēts potenciāli iespējamais attālinātā darbā strādājošo skaits Latvijā (2. attēls).

Aprēķinu rezultāti rāda, ka aptuveni $38 \%$ no nodarbinātajiem Latvijā potenciāli var strādāt attālinātā režīmā. Visās nozarēs ir vērojama relatīvi liela plaisa starp attālināti strādājošo un potenciāli iespējamo attālinātā darbā nodarbināto skaitu. Lielāka atpalicība ir valsts pārvaldes un izglìīibas nozarēs, kurās

6 Sostero, M., Milasi, S., Hurley, J., Fernández-Macías, E., Bisello, M. (2020). Teleworkability and the COVID-19 crisis: a new digital divide? Seville: European Commission, JRC121193. Pieejams: https://ec.europa.eu/jrc/sites/jrcsh/files/jrc121193.pdf 
2020. gadā attālināti strādājošo daḷa bija gandrīz uz pusi zemākā līmenī, nekā iespējams. Turklāt ražošanas nozarēs (ieskaitot būvniecību), kā arī tirdzniecības, izmitināšanas un ēdināšanas pakalpojumu nozarēs attālināti strādājošo īpatsvars tikai par 13 procentpunktiem bija zemāks nekā iespējamo attālinātā darba veicēju skaits. Kopumā tautsaimniecībā attālināta darbā strādājošo daḷa Covid-19 pandēmijas laikā 2020. gadā veidoja vidēji 15\% no nodarbināto kopskaita, kas ir gandrīz puse no iespējamā attālināta darba veicēju skaita un gandrīz 3 reizes vairāk, nekā tas bija pirms Covid-19 pandēmijas.

\section{Attālinātā darba ietekme uz produktivitāti}

Zinātnisko pētījumu skaits par attālinātā darba ietekmi uz produktivitāti pēdējo gadu laikā ir strauji pieaudzis. Tomēr ekonomikas literatūrā pagaidām nav vienprātības par attālinātā darba ietekmi uz produktivitāti.

Vairāki nozīmīgi pētījumi tika veikti vēl pirms Covid-19 pandēmijas. Piemēram, Stenfordas Universitātes veiktais pētījums kādā K̦īnas ceḷojumu aǵentūras uzṇēmumā, aptverot 16 tūkstošus darbinieku, parādīja, ka darba produktivitāte, strādājot attālināti, pieauga par 13\%, kas skaidrojams galvenokārt ar īsākām pauzēm darbadienas laikā, mazāku skaitu slimības dienu, labāku spēju koncentrēties un iespēju izdarīt vairāk. ${ }^{7}$ Turpretī Diego Battiston, pētot kādu publiskā sektora organizāciju Lielbritānijā, atklāja, ka produktivitāte ir augstāka, ja komandas biedri atrodas vienā telpā, un efekts ir lielāks steidzamiem un sarežǵītiem uzdevumiem. Attālinātais darbs nav piemērots uzdevumiem, kam nepieciešama tieša saziṇa. ${ }^{8}$

Vairāki autori uzskata, ka Covid-19 pandēmija ir vienkārši paātrinājusi jau esošās tendences ar attālinātā darba izmantošanu. Brents Neimans no Čikāgas Universitātes norāda uz trīs faktoriem, kas iepriekš kavēja attālinātā darba pieaugumu. Pirmais attiecas uz informāciju. Darba devēji vienkārši nezināja, vai klasteru veidošana birojā ir būtiska vai nav. Covid-19 pandēmijas ierobežojumi lāva viņiem to uzzināt. Otrais faktors attiecas uz koordināciju: vienai firmai bija grūti vienpusēji pāriet uz attālinātu darbu, iespējams, tāpēc, ka tās piegādātājiem vai klientiem tas būtu šķitis dīvaini. Tomēr pandēmija piespieda visus uzṇēmumus, kuri to varēja izdarīt, vienlaikus pāriet uz attālinātu darbu. Trešais faktors

Bloom, N., Liang, J., Roberts J., \& Jenny Ying, Z. (2015). Does Working from Home Work? Evidence from a Chinese Experiment. Quarterly Journal of Economics 130(1), 165-218.

8 Battiston, D., Blanes, J., Vidal, I., \& Kirchmaier, T. (2017). Is Distance Dead? Face-to-Face Communication and Productivity in Teams. CEPR Discussion Paper, No. 11924. 
ir saistīts ar uzṇēmumu ieguldījumiem pārejai no biroja uz darbu attālināti. Šādi ieguldījumi tiek veikti arī mājsaimniecību līmenī. ${ }^{9}$

Pētỉjumi par attālināto darbu balstīti galvenokārt uz aptauju respondentu subjektīvajiem uzskatiem. Turklāt gandrīz nav pētijumu, kas balstīti uz statistikas datiem. Attālinātā darba ietekmes izpētes galvenais izaicinājums ir nepieciešamo "specifisko" datu trūkums, kas stiprinātu pētniecības bāzi. Tā, piemēram, ir nepieciešams pilnveidot darba laika uzskaiti, izdalot kopèjā nostrādāto stundu statistikā attālinātā darba stundas. Šādu datu pieejamība palielinātu pētījumu kvalitāti un objektivitātes pakāpi.

\section{Faktori, kas ietekmē produktivitāti}

Attālinātais darbs var uzlabot vai kavēt uzṇēmuma darbību, un tā kopējais efekts ir būtiski atkarīgs no darbinieku efektivitātes, motivācijas un zināšanu radīšanas procesa un darba un kapitāla izmaksu samazināšanas iespējām, atbrīvojot resursus produktivitātes veicināšanai, veicinot inovācijas un reorganizāciju. Attālinātā darba nodrošināšana prasa atbilstošu IKT infrastruktūru. ${ }^{10}$

Ir vairāki faktori, kas ietekmē attālinātā darba produktivitāti - IKT nodrošinājums (programmaparatūra, dators, attāla piekḷuve biroja IT sistēmai, apmācỉba), darba organizācija un vadības stils (darbinieku autonomija, balstīta uz rezultātiem, vadības spēja pielāgoties), nodarbošanās raksturs (cik tas ir savstarpēji atkarīgs no citiem uzdevumiem, cik daudz radošuma ir nepieciešams, cik patstāvīgi to var veikt), darba vide mājās - privātās telpas, kas paredzēta darbam, trūkums daudziem nopietni ierobežo attālinātā darba efektivitāti.

Plašāka attālinātā darba ieviešana var radīt arī nozīmīgu papildu ietekmi uz darbinieku piesaisti un apmierinātìbu, jo ar tāldarbu var tikt palielināts darbinieku skaits, piemēram, nodarbinot augsti kvalificētus darbiniekus, kuri personisku iemeslu dēḷ ir piesaistìti konkrētai dzīvesvietai. Tāpat attālinātais darbs var pozitīvi ietekmēt kapitāla izmaksas, samazinot uzṇēmumam nepieciešamās biroja telpas un aprīkojumu, kā arī samazināt satiksmes sastrēgumus, oglekḷa un dạ̣iņu emisiju un pazemināt mājokḷu cenas ìpaši augsta blīvuma pilsētās.

\section{Attālinātā darba ietekmes uz produktivitāti makroekonomiskais novērtējums}

2020. gadā Covid-19 pandēmija ir atstājusi globāla mēroga spēcīgu un paliekošu ietekmi uz sociālekonomisko situāciju. Tomēr tās ietekme uz produktivitāti ir neskaidra. Covid-19 pandēmija ir mainījusi ne tikai darba tirgu, bet arī

What a way to make a living. The Economist, $12^{\text {th }}$ September, 2020, p. 20.

10 OECD. (2020). Productivity gains from teleworking in the post COVID-19 era: How can public policies make it happen? Pieejams: https://read.oecd-ilibrary.org/view/?ref=135_135250-u15liwp4jd\&title=Productivity-gains-from-teleworking-in-the-post-COVID-19-era 
statistikas iestāžu spēju mērīt to. Valdības atbalsta pasākumi, kā dīkstāves pabalsti, ietekmē darba produktivitātes uzskaiti (izlaide pret nodarbināto skaitu), jo cilvēks var nestrādāt (atrasties dīkstāvē), bet statistika to uztver kā strādājošo. Rēķinot pēc nostrādāto stundu skaita, 2020. gadā produktivitāte Latvijā kopumā ir augusi. Savukārt, rēḳinot pēc nodarbināto skaita, tā ir samazinājusies.

Balstoties uz CSP datiem, tika aprēḳinātas produktivitātes izmaiṇas pa nozarēm, tostarp nozarēs ar augstu attālinātā darba iespējamību, rēḳinot pievienoto vērtību gan pret nodarbināto skaitu, gan pret kopējo nostrādāto stundu skaitu. Aprēķins tika veikts par Covid-19 pandēmijas laika periodu 2020. gadā, t. i., no 2. līdz 4. ceturksnim, salīdzinājumā ar 2019. gada attiecīgo laika periodu (3. attēls).

Vērtējot Covid-19 pandēmijas ierobežošanas pasākumu ietekmi, jāsecina, ka darba tirgū korekcijas bija vidēji nedaudz mazākas nozarēs, kurās attālināta darba iespējas ir lielākas nekā nozarēs ar ierobežotu attālināta darba piemērošanas potenciālu. Turklāt darba tirgū gandrīz divreiz lielāks bija nostrādāto stundu nekā nodarbināto skaita samazinājums.

3. attēls. Pievienotās vērtības, nodarbināto skaita, nostrādāto stundu un produktivitātes izmainas 2020. gadā no 2. līdz 4. ceturksnim pa nozarēm Latvijā

(salīdzināmās cenās, izmaiņas procentos pret iepriekšējā gada attiecīgo periodu)

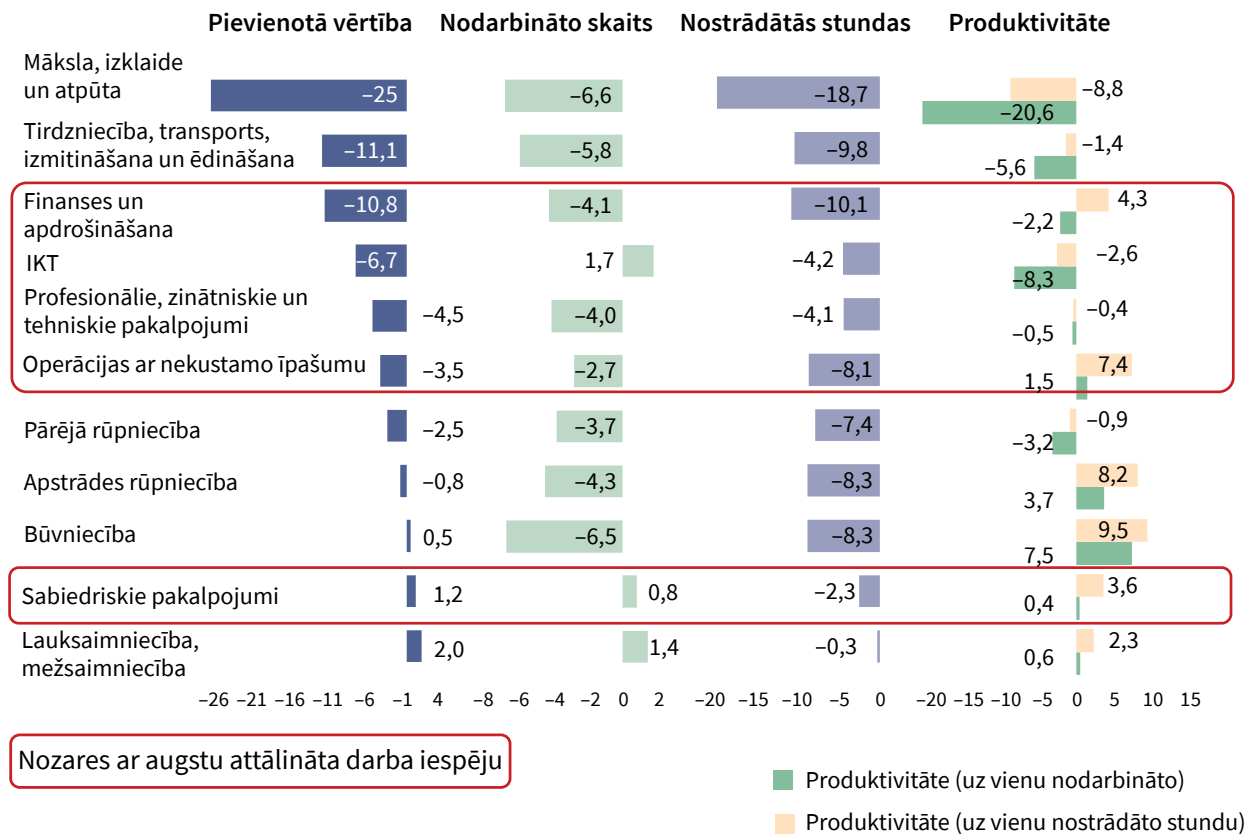




\section{Politikas izaicinājumi un virzieni attālinātā darba veicināšanai}

Lai efektīivi izmantotu attālinātā darba dotās iespējas celt produktivitāti un darbinieku apmierinātību arī pèc krīzes beigām, politikas veidotājiem ir gan jāpilnveido tiesiskais regulējums un sociālais dialogs, gan jāveicina investīcijas atbilstošas infrastruktūras izveidošanā un darbinieku apmācībā.

\section{Attālināts darbs ir izvēle un netiek "pārspīlēts"}

Personiskās saziņas loma, īpaši sarežğîtu uzdevumu veikšana, nozīmē, ka pārāk daudz attālinātā darba var samazināt darbinieku efektivitāti un ilgtermiņa produktivitātes pieaugumu. Nicholas Bloom norāda, ka pilna laika darbs mājās ir problemātisks trīs iemeslu dēḷ: ir grūti būt radošam no attāluma; ir grūti iedvesmoties un motivēt sevi; bez sociālās mijiedarbības darbinieku lojalitāte ir apslāpēta. ${ }^{11}$ Lai uzñēmuma līmenī palielinātu produktivitāti, veicot attālinātu darbu, ir svarīgi, lai darbinieku apmierinātība pieaugtu pietiekami, lai kompensētu potenciāli negatīvo ietekmi uz komunikāciju, zināšanu plūsmām un vadības uzraudzību. Nākotnes izaicinājums ir atrast optimālo proporciju starp attālināto un "tradicionālo" darbu. Pieeja, kad darbinieki velta nelielu daļu laika jaunu ideju izstrādei kopā ar kolẹgiem, faktiski var būt produktīvāka, nekā tas bija iepriekš. ${ }^{12}$

\section{Attālināta darba organizācija}

Darba procesa prasmīgs menedžments ir svarīgs produktivitātes palielināšanas faktors, un tā nozīme attālinātā darba režīmā palielinās. Ja darbs var tikt veikts attālināti, daudz kas ir atkarīgs no darba devēja spējas organizēt šādu darbu. Vadītājiem ir jāapgūst prasmes vadìt un saliedēt komandas, kuras ir "neredzamas", pieņemt lēmumus pastāvīgi mainīgos apstākḷ,os, būt gataviem reageèt uz pārmaiṇām. Valdībai būtu lietderīgi izstrādāt detalizētas attālināta darba vadlīnijas (rokasgrāmatu). Vadlīniju mērḳis - sniegt svarīgāko jautājumu pārskatu, kas jāṇem vērā, ieviešot attālināto darbu. Šādas vadlīnijas ir izstrādājušas Starptautiskā Darba organizācija u. c. ${ }^{13,14}$

11 Bloom, N. How working from home works out [online]. Stanford Institute for Economic Policy Research (SIEPR), June 2020. Pieejams: https://siepr.stanford.edu/research/publications/how-working-home-works-out

12 What a way to make a living. The Economist, $12^{\text {th }}$ September, 2020, p. 20.

13 International Labour Organization. (2020). An employers' guide on working from home in response to the outbreak of COVID-19. Pieejams: https:/www.ilo.org/wcmsp5/groups/public/---ed_dialogue/---act_ emp/documents/publication/wcms_745024.pdf

14 International Organisation of Employers. (2020, April). IOE Guidance on teleworking in the times of Covid-19. Pieejams: https://www.ioe-emp.org/fileadmin/user_upload/COVID-19/2020.04.03.IOE_Guideline_on_Teleworking_in_the_times_of_COVID-19.FINAL.pdf 


\section{Prasmes}

Lai izmantotu komunikācijas rīkus, ir nepieciešamas digitālās prasmes. Vienam no galvenajam politikas virzieniem jābūt digitālo prasmju palielināšanai sabiedrībā kopumā, specifiski orientējoties uz katru mērḳa grupu.

\section{"Slēptās virsstundas"}

Attālināts darbs var sabojāt darba laika kārtību un novest pie tā, ka "slēptās virsstundas" kḷūst par normu. Darba devēji ievēro galvenokārt rezultātus, bet ne laiku, kas pavadīts strādājot. Spēja izvēlēties, vai un cik daudz strādāt attālinātā darbā, var būt izšķiroša, lai sasniegtu produktivitātes pieaugumu. ${ }^{15}$ Ir jāuzlabo darba tiesību likumdošana, iekḷaujot attālinātā darba pamatnoteikumus sociālo partneru kopligumos.

\section{Attālinātā darba regulējums}

Attālinātais darbs Covid-19 pandēmijas laikā ir parādījis, ka pašreizējais tiesiskais regulējums ir novecojis. Pieaugošā mājas darba popularitāte rada spiedienu uz likumiem, kas tika pieņemti, balstoties uz pieṇēmumu, ka cilvēki strādās birojā. Ir vairāki jautājumi, kas prasa precīzāku tiesisko regulējumu, piemēram, darba ṇēmēju tiesības un pienākumi, vai firmas var uzraudzìt attālinātā darba ņēmējus, lai novērtētu viṇu produktivitāti, kurš ir atbildīgs par darba drošību u. c. ${ }^{16}$

\section{Valsts pārvaldes saziņas formas ar privātpersonām}

Lai arī pandēmijas laikā saziņā un darba pienākumu pildīšanā ievērojami pieaudzis videokonferenču lietojumprogrammu lietojums, videokonferenču izmantošana valsts pārvaldes un privātpersonu saziṇā vēl nav attīstījusies. Lai uzlabotu situāciju, ir nepieciešams izstrādāt jaunu valsts pārvaldes saziṇas formu ar privātpersonām - videokonferenci. Grozījumi nepieciešami Iesniegumu likumā (lai sniegtu iespēju iesniegt iesniegumus īsa audiovizuālā ieraksta veidā un digitālai apmeklētāju pieņemšanai), kā arī Administratīvās atbildības likumā (paredzot plašāku iespēju videokonferenču izmantošanai).

\section{Piemērota darba vide}

Politikas veidotājiem būtu jāveicina pasākumi, kas liek darba devējiem nodrošināt darbiniekus ar piemērotu darba vidi, strādājot attālinātā veidā,

\footnotetext{
15 OECD. (2020). Productivity gains from teleworking in the post COVID-19 era: How can public policies make it happen? Pieejams: https://read.oecd-ilibrary.org/view/?ref=135_135250-u15liwp4jd\&title=Productivity-gains-from-teleworking-in-the-post-COVID-19-era

16 What a way to make a living. The Economist, $12^{\text {th }}$ September, 2020, p. 11.
} 
piemēram, ar IKT aprīkojumu. ${ }^{17}$ Ir jāpilnveido regulējums par darba vides nodrošināšanu.

\section{Darba ñēmēju izmaksu segšana saistībā ar darbu ārpus biroja}

Darbinieku apmierinātība un līdz ar to arī efektivitāte var samazināties, ja dažas no attālinātā darba izmaksām nodrošina nevis uzṇēmums, bet tās sedz darbinieki, piemēram, ja darbiniekiem vajadzēja kompensēt dārgāku mājokli vai lielākus rēḳinus par elektrību. ${ }^{18}$ Tomēr, vai darba devējam būtu jāsedz visas izmaksas, piemēram, arī par darba n̦ēmēja mājokḷa apkuri ziemas periodā, ir diskutabls jautājums. Jebkurā gadījumā ir jāpilnveido regulējums par darba n̦ēmēju izmaksu segšanu saistībā ar darbu ārpus biroja u. tml.

\section{Atbalstoša sociālā infrastruktūra}

Vēl viens izaicinājums attālināta darba palielināšanai ir nodrošināt sociàlā atbalsta infrastruktūru darbiniekiem, piemēram, bērnu aprūpes iespējas. Bez šāda valsts vai uzñēmuma atbalsta palielinās darba n̦ēmēju slogs, īpaši sievietēm. Tāpat skolu slēgšana Covid-19 pandēmijas laikā strādājošajiem vecākiem uzlika papildu slogu.

\section{IKT infrastruktūra, datu drošība un privātums}

Politikas veidotājiem būtu jāatbalsta ātras, uzticamas un drošas IKT infrastruktūras pieejamības nodrošināšana uzṇēmumiem un darbiniekiem, turklāt ņemot vērā arī drošības un privātuma prasības, sākot ar aizsardzību no kiberuzbrukumiem līdz pārredzamības standartu noteikšanai attiecībā uz datu vākšanu no darbiniekiem.

Latvijā mājsaimniecību fiksētās platjoslas pārklājums atpaliek no ES vidējā rādītāja, izveidojusies digitālā plaisa starp pilsētu un laukiem. Digitālo tehnolog̣iju integrācija uzņēmumos Latvijā ir krietni zem ES vidējā līmeņa. Pusei Latvijas iedzivotāju trūkst digitālo pamatprasmju.

N̦emot to vērā, galvenajam politikas virzieniem jābūt:

- digitālo prasmju palielināšana sabiedrībā kopumā, specifiski orientējoties uz katru mērḳa grupu;

- jāizstrādā visaptveroša uzņēmumu digitalizācijas stratēgiija;

17 OECD. (2020). Productivity gains from teleworking in the post COVID-19 era: How can public policies make it happen? Pieejams: https://read.oecd-ilibrary.org/view/?ref=135_135250-u15liwp4jd\&title=Productivity-gains-from-teleworking-in-the-post-COVID-19-era

18 Turpat. 
- svarīgs instruments digitālajā laikmetā ir arī pastāvīgs dialogs ar uzṇēmējiem par jaunāko tehnolog̣iju attīstību un digitālās ekonomikas tendenču ietekmi uz to darbību;

- jāuzlabo digitalizācijas regulācija, jo ir jomas, kur ir ierobežotas iespējas piemērot jaunus biznesa model̦us;

- intelektuālā īpašuma tiesību jomas sakārtošana (datu sniedzējiem jāpaliek to turētājiem, platformas pašas par sevi ir tirgi, regulatīvais ietvars platformām, pieeja infrastruktūrai);

- starptautiskā sadarbība, īpaši attiecībā uz digitālās ekonomikas aplikšanu ar nodokḷiem, datu analīze un procesu mērīšana;

- pilnveidot regulējumu par datu aizsardzību, lai nodrošinātu privātuma tiesības un aizsardzību no kiberuzbrukumiem.

\section{Labākās pārvaldības prakses izplatīšana un sabiedrības attieksmes maiṇa par labu attālinātajam darbam}

Lai nodrošinātu zināšanu pārnesi, jāveicina uzņēmumu savstarpējā komunikācija, kā arī jānodrošina piekḷuve praktizējošajiem ekspertiem, kuri ir gatavi kḷùt par mentoriem un dalīties ar nepieciešamo informāciju. Politikas veidotājiem vajadzētu plašāk izplatìt labākās pārvaldības praksi, kas izstrādāta, reaǵējot uz attālinātā darba pastiprinātu izmantošanu. Vadītājiem jāpielāgojas attālinātā darba radītajām iespējām un izaicinājumiem. Sabiedrības attieksmes maiņu par labu attālinātajam darbam var panākt, rīkojot informācijas kampaṇas, parādot labākās pārvaldības prakses piemērus un uzsverot sabiedrības ieguvumus. Valsts sektora pielāgošana attālinātam darbam varētu kalpot kā piemērs, lai parādītu attālinātā darba priekšrocības

\section{Secinājumi}

Darba tirgus transformācija virzienā uz elastīgāku darbu bija vērojama jau ilgi pirms Covid-19 pandēmijas. Attālinātais darbs ir viens no darba tirgus transformācijas aspektiem, ko Covid-19 pandēmijas ierobežošanas pasākumi paātrināja, par ko liecina statistikas dati.

Pètījumi liecina, ka attālināts darbs var palielināt darba ņēmēju produktivitāti, samazināt izmaksas (piemēram, transporta), taču tas var izraisìt izolāciju un stresu, jo robeža starp darbu un mājām izplūst. Pastāv arī bažas, ka regulāru tikšanos trūkums ar kolēgiem varētu apslāpēt radošumu un mazināt komandas saliedètību.

Latvijā Covid-19 pandēmijas laikā ir notikusi strauja pāreja uz attālināto darbu. Tomēr vēl ir pāragri vērtēt, kādas tendences tas radīs ilgtermiņā. Nav īsti 
skaidrs, vai attālinātais darbs turpinās pieaugt arī pēc krīzes un cik lielā mērā attālinātais darbs Covid-19 pandēmijas laikā ir pozitīvi ietekmējis produktivitāti, jo vēl nav uzkrāta pietiekama datubāze. Turklāt produktivitāti attālinātā darba apstākḷ̆os Covid-19 pandēmijas laikā ietekmē daudzi citi papildu faktori, piemēram, darbinieku psihologiskais stāvoklis, skolu slēgšana utt. 